\title{
Colonization of Citrus and Citrus- related Germplasm by Diaphorina citri (Hemiptera: Psyllidae)
}

\author{
Catherine J. Westbrook ${ }^{1}$, David G. Hall ${ }^{2}$, Ed Stover, \\ and Yong Ping Duan \\ U.S. Horticultural Research Laboratory, U.S. Department of Agriculture, \\ Agricultural Research Service, 2001 South Rock Road, Fort Pierce, FL \\ 34945
}

\author{
Richard F. Lee \\ National Clonal Germplasm Repository for Citrus and Dates, U.S. Department \\ of Agriculture, Agricultural Research Service, 1060 Martin Luther King \\ Boulevard, Riverside, CA 92521
}

Additional index words. huanglongbing, greening disease, citrus breeding, Aurantioideae, Toddalioideae, Rutaceae, Asian citrus psyllid

\begin{abstract}
Huanglongbing (HLB) is a serious and devastating disease of citrus caused by Candidatus Liberibacter spp. and vectored by the Asian citrus psyllid, Diaphorina citri Kuwayama (Hemiptera: Psyllidae). The disease has the potential to greatly limit the production of citrus in Florida and other citrus-growing regions worldwide. Current control of $D$. citri and HLB is inadequate, but the identification and incorporation of D. citri resistance traits from uncultivated Citrus spp. and Citrus relatives is seen as a potential disease management strategy. In this study, seedlings of 87 Rutaceae seedsource genotypes, primarily in the orange subfamily Aurantioideae, were assessed in the field for their propensity in a free-choice situation for infestations of natural south Florida populations of $D$. citri. The majority of test populations surveyed hosted all three life stages of $D$. citri; however, there were significant differences among the test populations in the mean ranks for $D$. citri eggs $(F=3.13$, $\mathrm{df}=86, P<0.0001)$, nymphs $(\mathrm{F}=9.01, \mathrm{df}=86, P<0.0001)$, and adults $(\mathrm{F}=4.21, \mathrm{df}=86, P<0.0001)$. The only sampled test population that was completely avoided by all life stages of $D$. citri was seedlings of Casimiroa edulis Llave et Lex, commonly known as white sapote, which was one of the few plants included in the study belonging to the Rutaceae subfamily Toddalioideae. Although not completely avoided, very low levels of $D$. citri were found on two surveyed test populations of Poncirus trifoliata (L.) Raf, seedlings of 'Simmon's trifoliate' and 'Little-Leaf'. Poncirus trifoliata, the trifoliate orange, readily forms hybrids with Citrus spp., is commonly incorporated into rootstock varieties, and has been used in breedingadvanced scion material. The identification of partial resistance in $P$. trifoliata to $D$. citri could prove useful in future citrus breeding efforts aimed at reducing the incidence and spread of HLB. Determining if there is true resistance to $D$. citri in this and other germplasm sources with a low propensity for infestations in free-choice situations will require no-choice experiments.
\end{abstract}

The Asian citrus psyllid, Diaphorina citri, is a key pest in most citrus-growing regions around the world. D. citri nymphs feed exclusively on young elongating flush and feeding can retard leaf and shoot development (Michaud, 2004; Shivankar et al., 2000). In

Received for publication 29 Mar. 2011. Accepted for publication 10 May 2011.

This research was made possible by a grant from the Florida Citrus Research and Development Foundation.

We acknowledge and thank Montserrat Watson, Scott Ciliento, and Jonathan Worton (USDA-ARS, U.S. Horticultural Research Laboratory, Fort Pierce, FL) for their assistance.

${ }^{1}$ Current address: USAMRIID-Virology Division, 1425 Porter Street, Fort Detrick, MD 21702.

${ }^{2}$ To whom reprint requests should be addressed; e-mail David.Hall@ars.usda.gov. addition, the production of honey dew by feeding nymphs promotes the growth of sooty mold leading to a reduction in the photosynthetic capacity of the plant (Mead, 1977). However, the devastating economic damage caused by this insect comes from its ability to vector the phloem-limited Gram-negative bacteria, Candidatus Liberibacter spp., associated with citrus greening disease or huanglongbing (HLB) (Bové, 2006; Martinez and Wallace, 1967; Mead, 1977). Early in the development of HLB symptoms, leaves of citrus trees exhibit yellowed and/or blotchy mottle patterns followed by the development of chlorosis; trees exhibit stunted growth; and fruit become misshapen and inedible and drop prematurely. In 2 to 3 years trees can degenerate into a non-productive state, leading to the eventual death of the tree in $\approx 5$ to 8 years (Halbert and Manjunath, 2004; Tsai and Liu, 2000). HLB and $D$. citri have been known to occur in Asia for many years (Chen et al., 2010; Lin, 1956) and have subsequently spread to the Indian Ocean islands and the Americas (International Society for Infectious Diseases, 2004, 2005, 2008, 2009, 2010, 2011).

Diaphorina citri was found in Florida in 1998 (Halbert, 1998) and the discovery of HLB followed in 2005 (Halbert, 2005). The disease has seriously impacted Florida citrus fruit production, which between 2007 and 2008 was valued at U.S. $\$ 1.76$ billion with fresh fruit accounting for U.S. \$253 million and processed fruit U.S. $\$ 1.50$ billion (Rahmani and Hodges, 2009). D. citri is continuing to move into other citrus-producing regions in the United States, including California, Arizona, and Texas (da Graça et al., 2008; French et al., 2001), and it is likely that with time the disease will follow the spread of the vector.

The production of disease-resistant varieties is a vital component to a sustainable and long-term citrus management program. Insectresistant traits have been documented among members of the orange subfamily (Rutaceae: Aurantioideae) (Bowman et al., 2001; Luthria et al., 1989; Yang and Tang, 1988), and it is possible that the Aurantioideae germplasm reservoir contains traits that confer specific resistance to $D$. citri. The Aurantioideae, one of seven subfamilies of the Rutaceae, contains 33 genera and $\approx 210$ species native to the Old World tropics (Engler, 1931). The trees and shrubs of the orange subfamily are distinguished by persistent leaves except in three monotypic genera (Poncirus, Aegle, and Feronia), in several species of Clausena, and in one species of Murraya (M. alternans). Most members of the subfamily produce fruit with a leathery peel or hard shell; have fragrant white flowers; and leaves and fruit contain schizolysigenous oil glands that give off an aroma when touched (Swingle and Reece, 1967). Interspecific and to a lesser extent intergeneric hybridization within Citrus and among its relatives is common and has probably taken place in the wild for centuries (Nicolosi, 2007), thus making it difficult to fit the species concept to this group of plants. The taxonomic classification of the members of the Aurantioideae into tribes, subtribes, genera, and species is controversial and unresolved (Barrett and Rhodes, 1976; Bayer et al., 2009; Moore, 2001). Both the Tanaka (Tanaka, 1954, 1977) and Swingle (Swingle 1943; Swingle and Reece, 1967) systems are widely accepted for citrus taxonomy.

Previously published host plant information on $D$. citri suggests that this insect has a broad host range within the Aurantioideae and may even on occasion use Rutaceae species outside the orange subfamily as a food host (Aubert, 1990; Halbert and Manjunath, 2004; Yang et al., 2006). There is also evidence that there are differences in susceptibility to $D$. citri among common Citrus cultivars (Nehru et al., 2004; Tsagkarakis and Rogers, 2010; Tsai and Liu, 2000). However, in many of these studies, only a limited number of plants was surveyed often at a single time point, generally only presence or absence was 
recorded, and only limited information was presented on the susceptibility to each $D$. citri life stage. The objective of this study was to survey a Rutaceae planting, primarily composed of Aurantioideae seedling populations derived from diverse species, multiple times during the height of $D$. citri field populations for the presence and abundance of adults, nymphs, and eggs.

\section{Materials and Methods}

Seed source. Seeds representing a wide diversity of Citrus and Citrus relatives in the family Rutaceae were obtained from the National Clonal Germplasm Repository for Citrus and Dates (NCGRCD) at the University of California at Riverside (UCR), Riverside, CA. The seeds were derived from the Citrus Variety Collection of UCR, which was created nearly 100 years ago and contains more than 1000 accessions [each with a unique Citrus Research Center (CRC) number] of cultivated and wild species of Citrus and Citrus relatives, which are maintained as trees adjacent to the UCR campus. The Core Collection of citrus (Barkley, 2003) was included as seed sources also, because this subcollection of genotypes in the Citrus Variety Collection represents $\approx 85 \%$ of the genetic diversity as determined using 23 simple sequence repeat markers. Details of CRC genotypes used in this study can be obtained from the Citrus Variety Collection web site at http://www.citrusvariety. ucr.edu. All accessions from NCGRCD were members of the orange subfamily Aurantioideae, Rutaceae. Two more distant members of the subfamily Aurantioideae, Afraegle paniculata (Schum.) Engl. and Aegle marmelos (L.) Corr., as well as Casimiroa edulis (Llave et Lex), which is in the subfamily Toddalioideae, Rutaceae, were obtained from the Fruit and Spice Park of Miami/Dade County. Seeds of an additional Toddalioideae species, Zanthoxylum ailanthoides (L.), were obtained indirectly from Dr. John Ruter of the University of Georgia.

Seeds of 124 CRC accessions as well as additional material described previously were received and planted in a greenhouse at the USDA-ARS Laboratory in Fort Pierce, FL, in individual plastic cells $(3.8 \times 21 \mathrm{~cm})(\mathrm{SC}-10$ super cell Cone-tainers; Stuewe and Sons, Corvallis, OR) containing sterile soil. Seedlings from 87 seed-source genotypes (hereafter referred to as test populations in the text) were successfully propagated. It must be noted that members of the Rutaceae vary greatly in their incidence of nucellar embryony (reviewed in Frost and Soost, 1968) and so some of the seedling test populations were essentially genetically identical to the seed parent, whereas others represented half-sib families with only the seed-parent known. Seedlings were transplanted to 3.7-L containers when they were 4 to 7 months old and maintained on elevated benches in a greenhouse with an average diurnal temperature cycle of $35^{\circ} \mathrm{C}$ maximum and $23^{\circ} \mathrm{C}$ minimum in the summer and a diurnal cycle of $32{ }^{\circ} \mathrm{C}$ and $20^{\circ} \mathrm{C}$ in the winter. No supplemental light was supplied. Plants were watered with a dilute fertilizer mix weekly using water-soluble N:P:K $(20: 10: 20)$ at a rate of $150 \mathrm{mg} \cdot \mathrm{L}^{-1} \mathrm{~N}$.

Field evaluation for D. citri colonization. After 6 to 9 months in the greenhouse, eight single-plant replicates for each seedling test population were planted in a randomized complete block design in a plot with trees spaced at $0.6 \mathrm{~m}$ between trees in the row and $3.5 \mathrm{~m}$ between rows on a USDA-ARS research farm located near Fort Pierce, FL, in Saint Lucie County with most plants germinated in Aug. 2008 and field-planted during June and July 2009. The planting was regularly irrigated and no pesticides were applied to the plants during the study. Plants were fertilized using a program similar to that used for a new commercial planting of citrus. Plants were surveyed four times for $D$. citri infestations, approximately once per month from June to September of 2010.

Because the presence of immature D. citri is dependent on the presence of suitable flush, plants were sampled only if a minimum of one flush shoot was present. If no flush was present, then the plant replicate was excluded from the survey during that sampling period. Flush was defined as any shoot with developing leaves, which included breaking buds of new, unexpanded flush to shoots with expanded but tender young leaves (Hall and Albrigo, 2007). Overall plant and flush morphology of the test populations differed and a careful examination of each plant to locate flush was often necessary. Eggs, nymphs, and adult abundances were recorded as categorical counts based on a 0 to 3 ordinal scale. Egg sample categories per flush shoot were $0=$ no eggs present; 1 = from one to 20 eggs; $2=$ from 21 to 40 eggs; and $3=$ more than 40 eggs. Nymph sample categories per flush shoot were $0=$ no nymphs; $1=$ from one to 10 nymphs; $2=$ from 11 to 30 nymphs; and $3=$ more than 30 nymphs. Adult sample categories per plant were $0=$ no adults present; $1=$ from one to five; 2 = from six to 15 ; and $3=$ more than 15 adults. Egg, nymph, and adult density assignments to each categorical count were based on empirical observations of infestation densities in conjunction with published information (Hall et al., 2008).

For plants with multiple flush shoots, the first shoot examined that contained the life stage under assessment was used to determine the estimate per flush shoot for that replicate. For example, if the first flush shoot examined contained eggs, then the egg count for that shoot was the eggs per shoot estimate for that replicate. If, however, the shoot contained no eggs, subsequent flush shoots were examined until eggs were found or until all shoots were sequentially and exhaustively examined and it was determined no eggs were present on the plant. This was the same method used to count nymphs and additionally, if both eggs and nymphs were found on the same flush shoot, then both life stages were counted from the one shoot. Shoots were not removed and counts were made with as little disturbance of plant tissue and insects as possible while maintaining accuracy. The assessment of adult abun- dance was based on a 30-s examination of the entire plant, including flush, after which an entire plant adult count was recorded.

Statistical analyses. The counts from the 87 test populations collected over the 4 sampling months were analyzed as non-parametric repeated measure data using the F-approximation of the Friedman test (Ipe, 1987) and the associated rank sum multiple comparison test with PROC GLM in SAS (SAS Institute, 2008). The procedure was used after ranking the data within each sampling date from lowest to highest value using the PROC RANK procedure in SAS. The analyses of count data associated with each life stage (egg, nymph, and adult) were carried out separately.

\section{Results}

There were significant differences in abundance of $D$. citri eggs $(\mathrm{F}=3.13, \mathrm{df}=86, P<$ $0.0001)$, nymphs $(\mathrm{F}=9.01, \mathrm{df}=86, P<0.0001)$, and adults $(\mathrm{F}=4.21, \mathrm{df}=86, P<0.0001)$ among the 87 test populations according to the Friedman test. Mean ranks, group mean separations resulting from pairwise comparisons, and mean counts (zero to three) for the three life stages on test populations from the 87 seed sources are listed in Table 1. The overall order of seed-source genotypes in Table 1 is based on descending infestations of test populations by adult $D$. citri. All eight replicates did not always produce flush during each of the four sampling periods, so the total number of plants surveyed (designated by " $\mathrm{N}$ " in the column in Table 1) for each test population was often not the maximum 32 possible over the entire study period. Clausena excavata (CRC 3166), Balsamocitrus dawei (CRC 3514), Glycosmis pentaphylla (CRC 3285), and Casimiroa edulis were the only seed sources providing test populations in which all eight replicates could be surveyed four times.

Of the two test populations surveyed in the subfamily Toddalioideae, seedlings produced from $C$. edulis were completely avoided by $D$. citri, whereas Zanthoxylum ailanthoides seedlings were only host to adult $D$. citri. Many test populations from seed-source genotypes showed variability in mean rank among the $D$. citri life stages. Thus, a test population from a seed source with a high mean rank for eggs may have a lower mean rank for nymphs or adults. Table 2 lists the seed-source genotypes with test populations least colonized for each of the D. citri life stages: mean separation statistical group " $\mathrm{P}$ " for adults, group " $\mathrm{R}$ " for nymphs, and group "H" for eggs (refer to Table 1 for statistical groupings). A majority of the test populations that were least colonized were not in the Citrus genus. Six seed sources providing test populations fell into the lowest susceptibility group for all three life stages: C. edulis, Poncirus trifoliata (CRC 4007), P. trifoliata (CRC 3549), Glycosmis pentaphylla (CRC 3285), Clausena harmandiana (CRC 4034), and Z. ailanthoides.

Table 3 lists the seed-source genotypes providing test populations most heavily colonized by $D$. citri, which from Table 1 fell in 


\begin{tabular}{|c|c|c|c|c|c|c|c|c|}
\hline $\begin{array}{l}\text { Botanical name of seed } \\
\text { parent }^{y}\left(\mathrm{CRC}^{\mathrm{x}}\right)\end{array}$ & $\begin{array}{l}\text { Common name of } \\
\text { seed parent }\end{array}$ & $\mathrm{N}$ & $\begin{array}{l}\text { Mean adult } \\
\text { rank }^{\mathrm{w}}\end{array}$ & $\begin{array}{l}\text { Mean } \\
\text { count } \\
\text { adults } \\
(0-3)^{\mathrm{v}}\end{array}$ & $\begin{array}{l}\text { Mean nymph } \\
\text { rank }^{\mathrm{w}}\end{array}$ & $\begin{array}{c}\text { Mean } \\
\text { count } \\
\text { nymphs } \\
(0-3)^{\mathrm{v}}\end{array}$ & $\begin{array}{l}\text { Mean egg } \\
\text { rank }^{\mathrm{w}}\end{array}$ & $\begin{array}{l}\text { Mean count } \\
\text { eggs }(0-3)^{v}\end{array}$ \\
\hline $\begin{array}{c}{ }^{\bar{u}} \text { Citrus reticulata } \\
\text { Blanco (2590) }\end{array}$ & $\begin{array}{r}\text { Tien Chieh } \\
\text { mandarin }\end{array}$ & 27 & $446.4^{\mathrm{A}}$ & 1.11 & $350.6^{\mathrm{BCDEFG}}$ & 1.63 & $352.1^{\mathrm{ABC}}$ & 1.11 \\
\hline $\begin{array}{l}\text { Bergera koenigii L. } \\
\quad(3165)\end{array}$ & Curry tree & 31 & $427.3^{\mathrm{AB}}$ & 1.35 & $386.9^{\mathrm{ABCDEF}}$ & 1.81 & $358.5^{\mathrm{ABC}}$ & 1.29 \\
\hline $\begin{array}{l}\text { Murraya paniculata } \\
\text { (L.) Jack (1637) }\end{array}$ & Orange Jessamine & 29 & $399.9^{\mathrm{ABC}}$ & 1.07 & $333.0^{\mathrm{CDEFGHI}}$ & 1.48 & $368.6^{\mathrm{ABC}}$ & 1.17 \\
\hline C. medica L. (3523) & Diamante citron & 31 & $376.7^{\mathrm{ABCD}}$ & 0.97 & $384.5^{\mathrm{ABCDEFG}}$ & 1.81 & $304.5^{\mathrm{CDE}}$ & 1.00 \\
\hline $\begin{array}{l}{ }^{\mathrm{u}} C \text {. macrophylla Wester } \\
\text { (3842) }\end{array}$ & Alemow & 29 & $375.8^{\mathrm{ABCD}}$ & 0.83 & $373.1^{\mathrm{ABCDEFG}}$ & 1.72 & $386.5^{\mathrm{AB}}$ & 1.48 \\
\hline $\begin{array}{l}{ }^{\mathrm{u}} C \text {. limonia (L.) Osbeck } \\
\text { (712) }\end{array}$ & $\begin{array}{l}\text { Santa Barbara red } \\
\text { lime }\end{array}$ & 31 & $368.9^{\mathrm{BCD}}$ & 0.81 & $398.7^{\mathrm{ABCD}}$ & 1.94 & $365.9^{\mathrm{ABC}}$ & 1.26 \\
\hline $\begin{array}{l}{ }^{\mathrm{u}} C \text {. limettioides Tan. } \\
\text { (1482) }\end{array}$ & $\begin{array}{l}\text { Palestine sweet } \\
\text { lime }\end{array}$ & 24 & $365.6^{\mathrm{BCD}}$ & 0.75 & $400.4^{\mathrm{ABCD}}$ & 1.88 & $298.4^{\mathrm{CDE}}$ & 0.79 \\
\hline $\begin{array}{l}\text { C. reticulata Blanco } \\
\text { (3260) }\end{array}$ & $\begin{array}{l}\text { Soh Niamtra } \\
\text { mandarin }\end{array}$ & 31 & $361.6^{\mathrm{BCD}}$ & 0.87 & $364.9^{\mathrm{ABCDEFG}}$ & 1.65 & $319.3^{\mathrm{ABCD}}$ & 0.90 \\
\hline $\begin{array}{l}{ }^{\mathrm{u}} \text { C. } \operatorname{limon}(\mathrm{L} .) \text { Burn. } f . \\
(3176)\end{array}$ & $\begin{array}{l}\text { Frost nucellar } \\
\text { Lisbon }\end{array}$ & 26 & $357.4^{\mathrm{BCD}}$ & 0.81 & $370.9^{\mathrm{ABCDEFG}}$ & 1.73 & $345.2^{\mathrm{ABC}}$ & 1.08 \\
\hline${ }^{\mathrm{u}}$ C. aurantium L. (2717) & $\begin{array}{l}\text { Olivelands sour } \\
\text { orange }\end{array}$ & 25 & $357.3^{\mathrm{BCD}}$ & 0.76 & $366.4^{\mathrm{ABCDEFG}}$ & 1.72 & $296.5^{\mathrm{CDE}}$ & 0.80 \\
\hline $\begin{array}{l}\text { C. hybrid }(53-1-16 \\
\text { 'Clem' } \times \text { 'Hamlin') } \times \\
\text { Chinotto F1 }(3715)\end{array}$ & $\begin{array}{l}\text { Sour orange hybrid } \\
\text { ex-India }\end{array}$ & 25 & $357.1^{\mathrm{BCD}}$ & 0.76 & $320.7^{\text {DEFGHIJK }}$ & 1.36 & $336.7^{\mathrm{ABCD}}$ & 1.08 \\
\hline $\begin{array}{l}{ }^{\mathrm{u} C} \text { C. reticulata Blanco } \\
\text { (3558) }\end{array}$ & Fremont mandarin & 25 & $355.0^{\mathrm{BCDE}}$ & 0.76 & $322.7^{\text {CDEFGHIJK }}$ & 1.40 & $271.6^{\mathrm{CDEF}}$ & 0.68 \\
\hline${ }^{\mathrm{u} C}$ C. medica L. (3546) & $\begin{array}{l}\text { South Coast Field } \\
\text { Station citron }\end{array}$ & 29 & $353.8^{\mathrm{BCDE}}$ & 0.86 & $425.7^{\mathrm{AB}}$ & 2.07 & $317.5^{\mathrm{ABCD}}$ & 1.00 \\
\hline $\begin{array}{l}{ }^{\mathrm{u}} C \text {. limon L. Burm.f. } \\
\text { (3005) }\end{array}$ & $\begin{array}{l}\text { Frost nucellar } \\
\quad \text { Eureka lemon }\end{array}$ & 26 & $343.0^{\mathrm{CDEFG}}$ & 0.77 & $314.0^{\text {EFGHIJK }}$ & 1.38 & $317.3^{\mathrm{ABCD}}$ & 1.08 \\
\hline 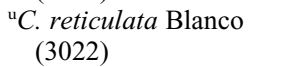 & Frua mandarin & 26 & $340.1^{\mathrm{CDEFGH}}$ & 0.73 & $301.1^{\text {GHIJK }}$ & 1.27 & $302.1^{\mathrm{CDE}}$ & 0.81 \\
\hline $\begin{array}{l}\times \text { Citrofortunella } \mathrm{sp} . \\
(3172)\end{array}$ & Tavares limequat & 29 & $339.9^{\mathrm{CDEFGH}}$ & 0.72 & $301.6^{\mathrm{GHIJK}}$ & 1.28 & $318.4^{\mathrm{ABCD}}$ & 0.86 \\
\hline C. aurantium L. (3929) & Gou Tou Cheng & 30 & $339.1^{\mathrm{CDEFGH}}$ & 0.70 & $309.0^{\text {GHIJK }}$ & 1.30 & $336.4^{\mathrm{ABCD}}$ & 1.03 \\
\hline${ }^{\mathrm{u}} C$. medica L. (661) & $\begin{array}{l}\text { Indian citron } \\
\text { hybrid }\end{array}$ & 26 & $333.9^{\mathrm{CDEFGHI}}$ & 0.73 & $337.3^{\mathrm{CDEFGH}}$ & 1.54 & $246.5^{\mathrm{DEFGH}}$ & 0.46 \\
\hline $\begin{array}{l}{ }^{\text {u}} C \text {. neo-aurantium }(C . \\
\text { obovoidea }+C \text {. unshiu } \\
\text { graft chimera) }(3816)\end{array}$ & $\begin{array}{l}\text { Kinkoji Unshiu } \\
\text { graft chimera }\end{array}$ & 28 & $330.1^{\text {CDEFGHI }}$ & 0.68 & $377.2^{\mathrm{ABCDEFG}}$ & 1.75 & $352.2^{\mathrm{ABC}}$ & 1.18 \\
\hline 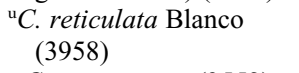 & Koster mandarin & 29 & $321.8^{\text {DEFGHI }}$ & 0.69 & $361.1^{\mathrm{ABCDEFG}}$ & 1.72 & $331.0^{\mathrm{ABCD}}$ & 1.03 \\
\hline$\times$ Citroncirus sp. (3552) & S-281 Citrangelo & 29 & $321.5^{\text {DEFGHI }}$ & 0.66 & $346.4^{\mathrm{CDEFG}}$ & 1.55 & $314.9^{\mathrm{ABCD}}$ & 0.83 \\
\hline $\begin{array}{l}{ }^{\mathrm{u}} \text { C.maxima (Burm.) } \\
\text { Merr. (2248) }\end{array}$ & $\begin{array}{l}\text { Kao Panne } \\
\text { pummelo }\end{array}$ & 28 & $319.5^{\mathrm{DEFGHI}}$ & 0.61 & $359.5^{\mathrm{ABCDEFG}}$ & 1.75 & $318.0^{\mathrm{ABCD}}$ & 1.00 \\
\hline 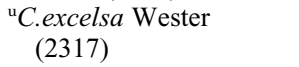 & Limon Real & 26 & $317.3^{\text {DEFGHIJ }}$ & 0.62 & $346.9^{\mathrm{BCDEFG}}$ & 1.58 & $322.2^{\mathrm{ABCD}}$ & 0.96 \\
\hline $\begin{array}{l}\text { C. paradisi Macf. } \\
\text { (3781) }\end{array}$ & $\begin{array}{l}\text { Tahitian pummelo } \\
\times \text { Star Ruby } \\
\text { grapefruit }\end{array}$ & 27 & $316.9^{\text {DEFGHIJ }}$ & 0.63 & $385.4^{\mathrm{ABCDEFG}}$ & 1.89 & $290.8^{\mathrm{CDE}}$ & 0.81 \\
\hline $\begin{array}{l}\text { Murraya paniculata } \mathrm{L} . \\
\quad(3171)\end{array}$ & var. ovatifoliolata & 30 & $316.5^{\text {DEFGHIJ }}$ & 0.70 & $294.4^{\text {GHIJKL }}$ & 1.20 & $345.8^{\mathrm{ABC}}$ & 1.03 \\
\hline $\begin{array}{l}\text { C. amblycarpa Och. } \\
(2485)\end{array}$ & $\begin{array}{l}\text { Nasnaran } \\
\text { mandarin }\end{array}$ & 29 & $313.9^{\text {DEFGHIJ }}$ & 0.62 & $302.1^{\mathrm{GHIJK}}$ & 1.28 & $336.7^{\mathrm{ABCD}}$ & 1.03 \\
\hline
\end{tabular}


Table 1. (Continued) Colonization of field-planted seedling test populations of Citrus and Citrus relatives to Diaphorina citri surveyed in Ft. Pierce, FL. ${ }^{2}$

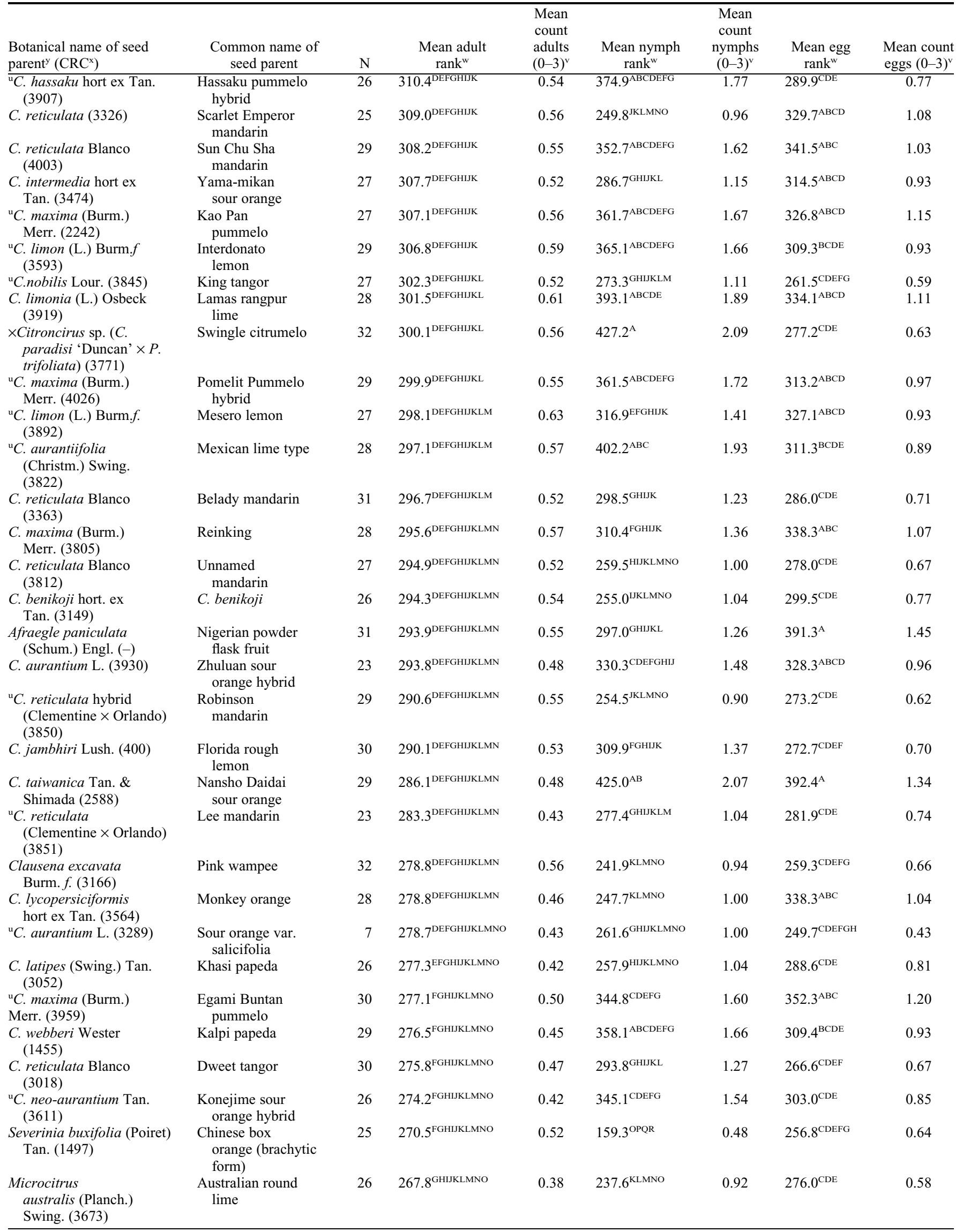


Table 1. (Continued) Colonization of field-planted seedling test populations of Citrus and Citrus relatives to Diaphorina citri surveyed in Ft. Pierce, FL. ${ }^{2}$

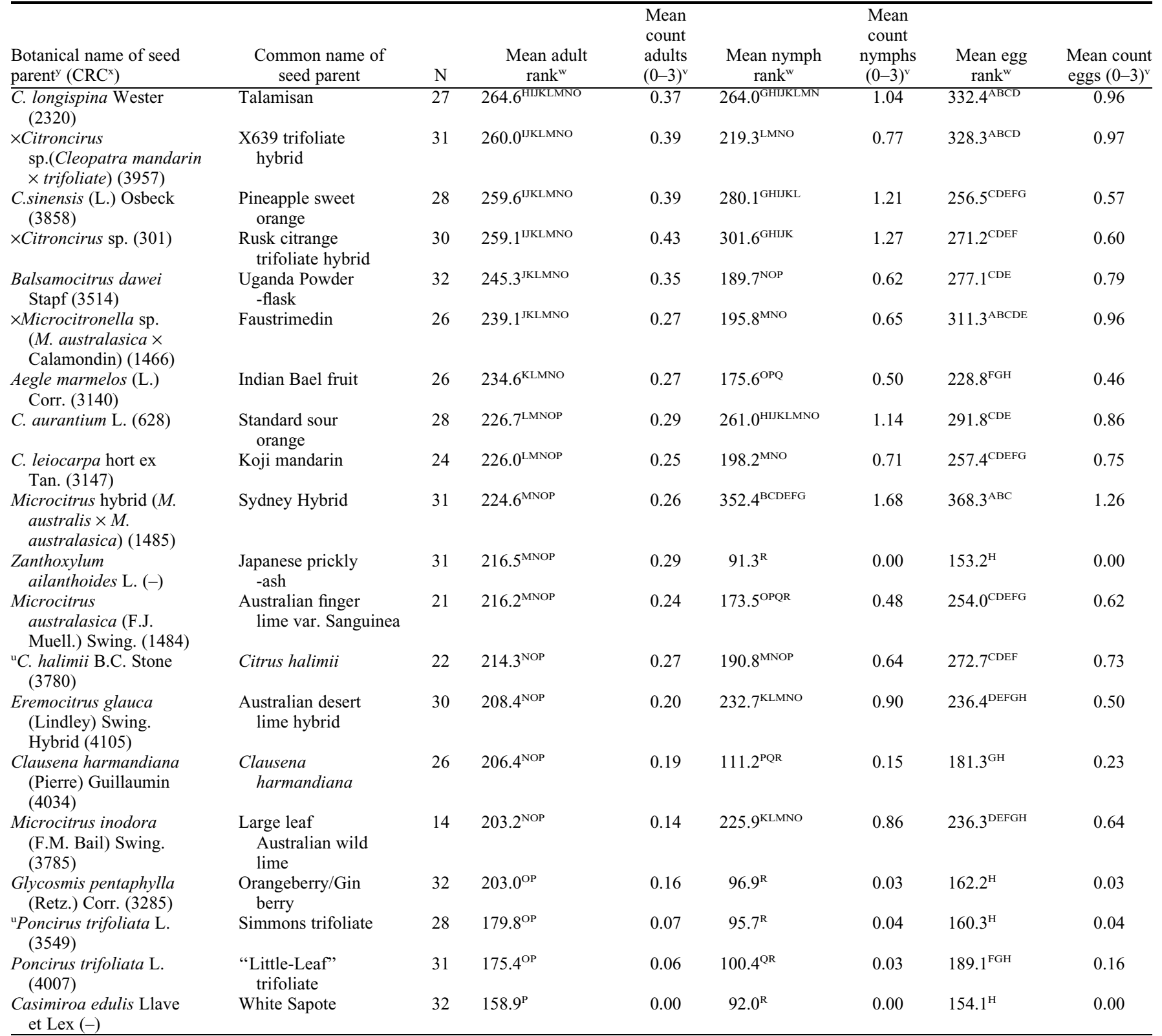

${ }^{2}$ Data are isted in order of decreasing colonization by adults. Members of the Rutaceae vary greatly in their incidence of nucellar embryony (reviewed in Frost and Soost, 1968) and so some of the plants tested were essentially genetically identical to the seed parent, whereas others represent half-sib families with only the seed parent known.

${ }^{\mathrm{y} B o t a n i c a l ~ a n d ~ c o m m o n ~ n a m e s ~ o f ~ s o u r c e ~ m a t e r i a l ~ a s ~ s p e c i f i e d ~ b y ~ U C ~ R i v e r s i d e ~ C i t r u s ~ V a r i e t y ~ C o l l e c t i o n, ~ R i v e r s i d e, ~ C A, ~ a s ~ d e f i n i n g ~ s p e c i f i c ~ a c c e s s i o n ~ n u m b e r ~}$ more detailed information can be found at http://www.citrusvariety.ucr.edu. parent.

${ }^{x}$ UC Riverside Citrus Variety Collection, Riverside, CA, accession number.

"Mean rank was calculated using the nonparametric Friedman's test with PROC GLM procedure in SAS and letters denoted shared groups based on pairwise comparisons of ranks.

vDetails of the $0-3$ rating scale for adults, nymphs and eggs is provided in the text.

"Botanical names from the Core Collection of Citrus, representing a broad range of genetic diversity as determined by simple sequence repeat markers (Barkley, 2003).

the mean separation statistical " $A$ " group for each life stage. Two test populations fell into the "A" group for each D. citri life stage: seedlings of Bergera koenigii (CRC 3165) and Citrus macrophylla (CRC 3842). The majority of the test populations exhibiting high susceptibility to D. citri were from seed sources in the Citrus genus, but the following non-Citrus test populations were also heavily colonized: seedlings of B. koenigii, Murraya paniculata (CRC 1637), xCitroncirus sp. (CRC 3771),
Afraegle paniculata, Microcitrus hybrid (CRC 1485), M. paniculata (CRC 3171), $\times$ Citroncirus sp. (CRC 3957), $\times$ Citrofortunella sp. (CRC 3172), $\times$ Citroncirus sp. (CRC 3552), and $\times$ Microcitronella $\mathrm{sp}$. (CRC 1466).

\section{Discussion}

In this study, several test populations were identified that were avoided as a host plant by D. citri. Of the six test populations that were least colonized by all three life stages, only seedlings from the genus Poncirus Raf. were in the "true citrus fruit trees," a group designated by Swingle and thus sexually compatible with Citrus. Swingle considered the monotypic genus Poncirus to be the most genetically isolated and aberrant of the "true citrus fruit trees" as a result of characters such as trifoliate deciduous leaves and cold-hardiness (Swingle, 1943; Swingle and Reece, 1967). However, recent phylogenetic work on the genera of the 
Table 2. Test populations colonized least by each life stage of $D$. citri among seedlings of 87 seed-source genotypes of Citrus and Citrus relatives surveyed in Ft. Pierce, FL. ${ }^{\mathrm{z}}$

\begin{tabular}{|c|c|c|c|c|}
\hline Botanical name of seed parent & Common name of seed parent & $\mathrm{CRC}$ & Mean rank & $\begin{array}{l}\text { Mean } \\
\text { count } \\
(0-3) \\
\end{array}$ \\
\hline \multicolumn{5}{|l|}{$\overline{\text { Adults }}$} \\
\hline Casimiroa edulis Llave et Lex & White Sapote & - & 158.9 & 0.00 \\
\hline Poncirus trifoliata $\mathrm{L}$. & "Little-Leaf" trifoliate & 4007 & 175.4 & 0.06 \\
\hline Poncirus trifoliata L. & Simmons trifoliate & 3549 & 179.8 & 0.07 \\
\hline Glycosmis pentaphylla (Retz.) Corr. & Orangeberry/Gin berry & 3285 & 203.0 & 0.16 \\
\hline Microcitrus inodora (F.M. Bail) Swing. & Large leaf Australian wild lime & 3785 & 203.2 & 0.14 \\
\hline Clausena harmandiana (Pierre) Guillaumin & Clausena harmandiana & 4034 & 206.4 & 0.19 \\
\hline Eremocitrus glauca (Lindley) Swing. hybrid & Australian desert lime hybrid & 4105 & 208.4 & 0.20 \\
\hline Citrus halimii B.C. Stone & Citrus halimii & 3780 & 214.3 & 0.27 \\
\hline Microcitrus australasica (F.J. Muell.) Swing. & Australian finger lime var. Sanguinea & 1484 & 216.2 & 0.24 \\
\hline Zanthoxylum ailanthoides $\mathrm{L}$. & Japanese prickly-ash & - & 216.5 & 0.29 \\
\hline $\begin{array}{l}\text { Microcitrus hybrid (M. australis } \times M \text {. } \\
\text { australasica) }\end{array}$ & Sydney Hybrid & 1485 & 224.6 & 0.26 \\
\hline Citrus leiocarpa hort ex Tan. & Koji mandarin & 3147 & 226.0 & 0.25 \\
\hline Citrus aurantium $\mathrm{L}$. & Standard sour orange & 628 & 226.7 & 0.29 \\
\hline \multicolumn{5}{|l|}{ Nymphs } \\
\hline Zanthoxylum ailanthoides $\mathrm{L}$. & Japanese prickly-ash & - & 91.3 & 0.00 \\
\hline Casimiroa edulis Llave et Lex & White Sapote & - & 92.0 & 0.00 \\
\hline Poncirus trifoliata L. & Simmons trifoliate & 3549 & 95.7 & 0.04 \\
\hline Glycosmis pentaphylla (Retz.) Corr. & Orangeberry/Gin berry & 3285 & 96.9 & 0.03 \\
\hline Poncirus trifoliata L. & "Little-Leaf" trifoliate & 4007 & 100.4 & 0.03 \\
\hline Clausena harmandiana (Pierre) Guillaumin & Clausena harmandiana & 4034 & 111.2 & 0.15 \\
\hline Severinia buxifolia (Poiret) Tan. & Chinese box orange (brachytic form) & 1497 & 159.3 & 0.48 \\
\hline Microcitrus australasica (F.J. Muell.) Swing. & Australian finger lime var. Sanguinea & 1484 & 173.5 & 0.48 \\
\hline \multicolumn{5}{|l|}{ Eggs } \\
\hline Zanthoxylum ailanthoides $\mathrm{L}$. & Japanese prickly-ash & - & 153.2 & 0.00 \\
\hline Casimiroa edulis Llave et Lex & White Sapote & - & 154.1 & 0.00 \\
\hline Poncirus trifoliata $\mathrm{L}$. & Simmons trifoliate & 3549 & 160.3 & 0.04 \\
\hline Glycosmis pentaphylla (Retz.) Corr. & Orangeberry/Gin berry & 3285 & 162.2 & 0.03 \\
\hline Clausena harmandiana (Pierre) Guillaumin & Clausena harmandiana & 4034 & 181.3 & 0.23 \\
\hline Poncirus trifoliata L. & "Little-Leaf" trifoliate & 4007 & 189.1 & 0.16 \\
\hline Aegle marmelos (L.) Corr. & Indian Bael fruit & 3140 & 228.8 & 0.46 \\
\hline Microcitrus inodora (F.M. Bail) Swing. & Large leaf Australian wild lime & 3785 & 236.3 & 0.64 \\
\hline Eremocitrus glauca (Lindley) Swing. hybrid & Australian desert lime hybrid & 4105 & 236.4 & 0.50 \\
\hline Citrus medica $\mathrm{L}$. & Indian citron hybrid & 661 & 246.5 & 0.46 \\
\hline Citrus aurantium $\mathrm{L}$. & Sour orange var. salicifolia & 3289 & 249.7 & 0.43 \\
\hline
\end{tabular}

${ }^{\mathrm{z}}$ For each life stage, seed-source genotypes are listed in order of increasing colonization of their seedling test populations. Members of the Rutaceae vary greatly in their incidence of nucellar embryony (reviewed in Frost and Soost, 1968) and so some of the plants tested were essentially genetically identical to the seed parent, whereas others represent half-sib families with only the seed parent known.

Aurantioidea keeps P. trifoliata in an isolated position but nested within a newly constructed monophyletic Citrus clade, renaming it Citrus trifoliata (Bayer et al., 2009). Consensus dendrograms further indicate that $P$. trifoliata may be more closely related to certain cultivated species of Citrus than other genera of the "true citrus fruit trees" such as Microcitrus, Eremocitrus, and Clymenia (Bayer et al., 2009). Further exploration of the basis of avoidance of $P$. trifoliata by $D$. citri observed in this study would be a worthwhile investment because of the important role of $P$. trifoliata in citrus breeding programs. Poncirus trifoliata is graft-compatible and hybridizes with Citrus, is the dominant rootstock in China, and since 1892 in Florida has been used as a rootstock alone or in hybrid form (Krueger and Navarro, 2007; Ziegler and Wolfe, 1981). It is an important parent in intergeneric hybrids with Citrus, which are collectively referred to as $\times$ Citroncirus (Krueger and Navarro, 2007). A number of advanced selections with Poncirus trifoliata in their pedigree are present in citrus breeding programs; use of $P$. trifoliata has been largely directed at cold-hardiness, but it is possible that some of these selections, which approach commercial fruit quality, may have $D$. citri resistance as well.

Four $\times$ Citroncirus sp. were included among the 87 seed sources providing test populations listed in Table 1: S-281 citrangelo (CRC 3552), Swingle citrumelo (CRC 3771), X639 (CRC 3957), and Rusk (CRC 301). Three of these seed-source genotypes-Swingle citrumelo, X641, and S-281 citrangelo-are also listed in Table 3 as a result of the high affinity of their test populations for D. citri. Based on our findings, seedlings of the $\times$ Citroncirus seedsource genotypes did not seem to inherit the apparent resistance found in pure $P$. trifoliata, but this may not be true for all hybrids. A further examination of a broader variety of $P$. trifoliata selections and $\times$ Citroncirus is currently underway.

Seedling test populations from species within other genera among the "true citrus fruit trees" that were surveyed included Eremocitrus glauca (CRC 4105), Microcitrus australasica (CRC 1484), M. australis (3673), M. hybrid (CRC 1485), M. inodora (CRC 3785), Severinia buxifolia (CRC 1497), $\times$ Citrofortunella $\mathrm{sp}$. (CRC 3172), and $\times$ Microcitronella sp. (CRC 1466). None of the test populations from these seed sources were avoided by all three $D$. citri life stages. Seedlings of Eremocitrus glauca, $M$. inodora, M. australasica, and the $M$. hybrid seed-source genotype were avoided by adults as food and resting hosts, but the $M$. hybrid test population was in the most susceptible egg group, E. glauca; $M$. inodora test populations had a moderately high rank for nymphs; and the $M$. australasica test population had a moderately high rank for eggs. Similarly, low numbers of nymphs were found on S. buxifolia seedlings, but this test population showed moderate affinity for $D$. citri adults and eggs. Although members of the genus Fortunella were received as seed from the Citrus Variety Collection, poor germination prevented their inclusion in the planting; however, two Fortunella hybrid test populations in the planting (seedlings of $\times$ Citrofortunella $\mathrm{sp}$. and $\times$ Microcitronella $\mathrm{sp}$.) showed susceptibility to all life stages of D. citri with high mean ranks for eggs in particular.

Seedling test populations of Glycosmis pentaphylla and Clausena harmandiana, members of Swingle's "remote citroid fruits," also were colonized less by all three life stages of $D$. citri. These species are sexually incompatible with the genus Citrus, preventing the creation of resistant intergeneric crosses through sexual 
Table 3. Test populations colonized most by each life stage of $D$. citri among seedlings of 87 seed-source genotypes of Citrus and Citrus relatives surveyed in Ft. Pierce, FL. ${ }^{2}$

\begin{tabular}{|c|c|c|c|c|}
\hline Botanical name of seed parent & Common name of seed parent & $\mathrm{CRC}$ & $\begin{array}{c}\text { Mean } \\
\text { rank }\end{array}$ & $\begin{array}{l}\text { Mean } \\
\text { count } \\
(0-3)\end{array}$ \\
\hline \multicolumn{5}{|l|}{$\overline{\text { Adults }}$} \\
\hline Citrus reticulata Blanco & Tien Chieh mandarin & 2590 & 446.4 & 1.11 \\
\hline Bergera koenigii L. & Curry tree & 3165 & 427.3 & 1.35 \\
\hline Murraya paniculata (L.) Jack & Orange Jessamine & 1637 & 399.9 & 1.07 \\
\hline Citrus maxima (Burm.) Merr. & Mato Buntan pummelo & 3945 & 386.8 & 0.90 \\
\hline Citrus medica $\mathrm{L}$. & Diamante citron & 3523 & 376.7 & 0.97 \\
\hline Citrus macrophylla Wester & Alemow & 3842 & 375.8 & 0.83 \\
\hline \multicolumn{5}{|l|}{ Nymphs } \\
\hline $\begin{array}{l}\times \text { Citroncirus } \text { sp. }(C \text {. paradisi } \\
\text { 'Duncan' } \times P . \text { trifoliata })\end{array}$ & Swingle citrumelo & 3771 & 427.2 & 2.09 \\
\hline Citrus medica $\mathrm{L}$. & South Coast Field Station citron & 3546 & 425.7 & 2.07 \\
\hline Citrus taiwanica Tan. \& Shimada & Nansho Daidai sour orange & 2588 & 425.0 & 2.07 \\
\hline Citrus aurantifolia (Christm.) Swing. & Mexican lime type & 3822 & 402.2 & 1.93 \\
\hline Citrus limettioides Tan. & Palestine sweet lime & 1482 & 400.4 & 1.88 \\
\hline Citrus limonia (L.) Osbeck & Santa Barbara red lime & 712 & 398.7 & 1.94 \\
\hline Citrus limonia (L.) Osbeck & Lamas rangpur lime & 3919 & 393.1 & 1.89 \\
\hline Citrus limon (L.) Burm.f. & Local variety from Iran & 3885 & 387.0 & 1.81 \\
\hline Bergera koenigii L. & Curry tree & 3165 & 386.9 & 1.81 \\
\hline Citrus paradisi Macf. & Tahitian pummelo $\times$ Star Ruby & 3781 & 385.4 & 1.89 \\
\hline Citrus medica $\mathrm{L}$. & Diamante citron & 3523 & 384.5 & 1.81 \\
\hline Citrus hassaku, hort ex Tan. & Hassaku pummelo hybrid & 3942 & 381.7 & 1.83 \\
\hline Citrus aurantifolia (Christm.) Swing. & India lime & 2450 & 379.0 & 1.79 \\
\hline $\begin{array}{l}\text { Citrus neo-aurantium (C. obovoidea }+ \\
\text { C. unshiu graft } \\
\text { chimera) }\end{array}$ & Kinkoji Unshiu graft chimera & 3816 & 377.2 & 1.75 \\
\hline Citrus hassaku hort ex Tan. & Hassaku pummelo hybrid & 3907 & 374.9 & 1.77 \\
\hline Citrus macrophylla Wester & Alemow & 3842 & 373.1 & 1.72 \\
\hline Citrus limon (L.) Burn.f. & Frost nucellar Lisbon & 3176 & 370.9 & 1.73 \\
\hline Citrus volkameriana/C. limonia Osbeck & Volkamer lemon hybrid & 3050 & 369.9 & 1.69 \\
\hline Citrus aurantium $\mathrm{L}$. & Olivelands sour orange & 2717 & 366.4 & 1.72 \\
\hline Citrus limon (L.) Burm. $f$ & Interdonato lemon & 3593 & 365.1 & 1.66 \\
\hline Citrus reticulata Blanco & Soh Niamtra mandarin & 3260 & 364.9 & 1.65 \\
\hline Citrus maxima (Burm.) Merr. & Kao Pan pummelo & 2242 & 361.7 & 1.67 \\
\hline Citrus maxima (Burm.) Merr. & Pomelit pummelo hybrid & 4026 & 361.5 & 1.72 \\
\hline Citrus reticulata Blanco & Koster mandarin & 3958 & 361.1 & 1.72 \\
\hline Citrus davaoens & Davao lemon (Papeda) & 2427 & 361.0 & 1.70 \\
\hline Citrus maxima & Kao Panne pummelo & 2248 & 359.5 & 1.75 \\
\hline Citrus webberi Wester & Kalpi papeda & 1455 & 358.1 & 1.66 \\
\hline Citrus reticulata Blanco & Som Keowan mandarin & 3752 & 357.4 & 1.57 \\
\hline Citrus reticulata Blanco & Sun Chu Sha mandarin & 4003 & 352.8 & 1.62 \\
\hline \multicolumn{5}{|l|}{ Eggs } \\
\hline Citrus taiwo & e & 2588 & 392.4 & 1.34 \\
\hline Afraegle paniculata (Schum.) Engl. & Nigerian powder flask fruit & 297 & 391.3 & 1.45 \\
\hline Citrus macrophylla Wester & Alemow & 3842 & 386.5 & 1.48 \\
\hline Murraya paniculata (L.) Jack & Orange Jessamine & 1637 & 368.6 & 1.17 \\
\hline $\begin{array}{l}\text { Microcitrus hybrid (M. australis } \times \\
\text { M. australasica) }\end{array}$ & Sydney Hybrid & 1485 & 368.3 & 1.26 \\
\hline Citrus limonia (L.) Osbeck & Barbara red lime & 712 & 365.9 & 1.26 \\
\hline Bergera koenigii L. & Curry tree & 3165 & 358.5 & 1.29 \\
\hline Citrus maxima (Burm.) Merr. & Egami Buntan pummelo & 3959 & 352.3 & 1.20 \\
\hline $\begin{array}{l}\text { Citrus neo-aurantium (C. obovoidea }+ \\
\text { C. unshi graft chimera) }\end{array}$ & Kinkoji Unshiu graft chimera & 3816 & 352.2 & 1.18 \\
\hline Citrus reticulat & Tien Chieh mandarin & 2590 & 352.1 & 1.11 \\
\hline Citrus reticulata Blanco & Som Keowan mandarin & 3752 & 346.7 & 1.00 \\
\hline Murraya paniculata $\mathrm{L}$. & var. ovatifoliolata & 3171 & 345.8 & 1.03 \\
\hline Citrus limon (L.) Burn. $f$. & Frost nucellar Lisbon & 3176 & 345.2 & 1.08 \\
\hline Citrus maxima (Burm.) Merr. & Mato Buntan pummelo & 3945 & 343.0 & 1.19 \\
\hline Citrus reticulata Blanco & Sun Chu Sha mandarin & 4003 & 341.5 & 1.03 \\
\hline Citrus maxima (Burm.) Merr. & Reinking pummelo & 3805 & 338.3 & 1.07 \\
\hline Citrus lycopersicaformis hort ex Tan. & Monkey orange & 3564 & 338.3 & 1.04 \\
\hline Citrus hassaku, hort ex Tan. & Hassaku pummelo hy & 3942 & 338.2 & 1.10 \\
\hline $\begin{array}{l}\text { Citrus hybrid (53-1-16 'Clem' } \times \\
\text { 'Hamlin') } \times \text { Chinotto F1 }\end{array}$ & Sour orange hybrid ex-India & 3715 & 336.7 & 1.08 \\
\hline Citrus amblycarpa Och. & rin & 2485 & 336.7 & 1.03 \\
\hline Citrus aurantium L. & Gol & 3929 & 336.4 & 1.03 \\
\hline Citrus limonia L. Osbeck & Lamas rangpur lime & 3919 & 334.1 & 1.11 \\
\hline Citrus limon (L.) Burm.f. & Local variety from Iran & 3885 & 333.0 & 1.04 \\
\hline Citrus longispina Wester & Talamisan & 2320 & 332.4 & 0.96 \\
\hline Citrus reticulata Blanco & Koster mandarin & 3958 & 331.0 & 1.03 \\
\hline Citrus reticulata Blanco & $\begin{array}{l}\text { Scarlet Emperor mandarin } \\
\text { Pankan }\end{array}$ & 3326 & 329.7 & 1.08 \\
\hline
\end{tabular}

(Continued on next page) hybridization. However, these species may be a source of resistant traits that could be used through genetic transformation. Glycosmis pentaphylla is partially graft-compatible with some citrus species (Bowman et al., 2001), and the biochemical basis of resistance in $G$. pentaphylla to a citrus weevil pest, Diaprepes abbreviatus (L.) (Shapiro et al., 1997, 2000), might offer some cross-resistance to other insects pests such as D. citri.

The majority of the test populations in this study did not exhibit resistance to $D$. citri based on infestation levels we observed, confirming that $D$. citri has a large host range among the Aurantioideae with some of the most susceptible test populations derived from seed sources outside the Citrus genus. Even seedlings of $Z$. ailanthoides, one of the two members surveyed in the subfamily Toddalioideae, appeared to be a suitable feeding and resting host for adult $D$. citri. It would be worthwhile to investigate the susceptibility of additional non-Aurantioidea taxa within the Rutaceae to broaden the search for resistant traits and document the true breadth of the $D$. citri host range. With respect to adult susceptibility, the following seed sources provided test populations with the highest adult mean ranks: C. reticulata (CRC 2590), B. koenigii, M. paniculata (1637), C. maxima (CRC 3945), C. medica (CRC 3523), and C. macrophylla. One test population of a Citrus reticulata seed source (CRC 2590), 'Tien Chieh', was also in the highest susceptibility group for $D$. citri eggs. This was one of 13 C. reticulata selections among the 87 seed sources providing test populations, and although it produced the only $C$. reticulata test population in the highest adult susceptibility group, five other test populations with $C$. reticulata seed sources were identified as susceptible to infestations of eggs and nymphs (Table 3 ) with three of the $C$. reticulata seed sources providing test populations in both the highest nymph and egg susceptibility groups: 'Soh Niamtra' (CRC 3260), 'Koster' (CRC 3958), and 'Som Keowan' (CRC 3752) mandarins.

Seedlings of Citrus macrophylla (alemow) and B. koenigii (curry leaf tree) were the only two test populations that were in the highest susceptibility groups for all three life stages, and both are used in research facilities as host plants for laboratory colonies of $D$. citri (Tsagkarakis and Rogers, 2010). Interestingly, B. koenigii is a sister taxon to the genus Clausena (Bayer et al., 2009), yet its seedlings were heavily colonized by $D$. citri in our studies, whereas seedlings of $C$. harmandiana were not, suggesting that phylogenetic distance among Aurantioideae genotypes may have no influence on $D$. citri susceptibility. Murraya paniculata (represented by CRC 1637 in our study), "orange jasmine," is known as second only to commercial citrus as a preferred host for D. citri in China (Yang et al., 2006), and this genotype has also frequently been used as a host plant for $D$. citri colonies (Wenninger and Hall, 2007). The recognition of this test population as highly susceptible to $D$. citri was therefore not surprising. Because of orange jasmine's wide use as an ornamental in many 
Table 3. (Continued) Test populations colonized most by each life stage of $D$. citri among seedlings of 87 seed-source genotypes of Citrus and Citrus relatives surveyed in Ft. Pierce, FL. ${ }^{2}$

\begin{tabular}{|c|c|c|c|c|}
\hline Botanical name of seed parent & Common name of seed parent & $\mathrm{CRC}$ & $\begin{array}{c}\text { Mean } \\
\text { rank }\end{array}$ & $\begin{array}{l}\text { Mean } \\
\text { count } \\
(0-3)\end{array}$ \\
\hline $\begin{array}{l}\times \text { Citroncirus sp. [Cleopatra } \\
\text { mandarin } \times \text { trifoliate }(\mathrm{X} 639)]\end{array}$ & X639 trifoliate hybrid & 3957 & 328.3 & 0.97 \\
\hline Citrus aurantium L. & Zhuluan sour orange hybrid & 3930 & 328.3 & 0.96 \\
\hline Citrus limon (L.) Burm. $f$. & Mesero lemon & 3892 & 327.1 & 0.93 \\
\hline Citrus maxima (Burm.) Merr. & Kao Pan pummelo & 2242 & 326.8 & 1.15 \\
\hline Citrus excelsa Wester & Limon Real & 2317 & 322.2 & 0.96 \\
\hline Citrus reticulata Blanco & Soh niamtra mandarin & 3260 & 319.3 & 0.90 \\
\hline$\times$ Citrofortunella $\mathrm{sp}$. & Tavares limequat & 3172 & 318.4 & 0.86 \\
\hline Citrus maxima (Burm.) Merr. & Kao Panne pummelo & 2248 & 318.0 & 1.00 \\
\hline Citrus medica $\mathrm{L}$. & South Coast Field Station citron & 3546 & 317.5 & 1.00 \\
\hline Citrus limon L. Burm. $f$. & Frost nucellar Eureka lemon & 3005 & 317.3 & 1.08 \\
\hline Citrus davaoensis (Wester) Tan. & Davao lemon (Papeda) & 2427 & 315.9 & 0.93 \\
\hline$\times$ Citroncirus sp. & S-281 Citrangelo & 3552 & 314.9 & 0.83 \\
\hline Citrus intermedia hort ex Tan. & Yama-mikan sour orange & 3474 & 314.5 & 0.93 \\
\hline Citrus maxima (Burm.) Merr. & Pomelit Pummelo hybrid & 4026 & 313.2 & 0.97 \\
\hline $\begin{array}{l}\times \text { Microcitronella sp. }(M . \\
\text { australasica } \times \text { Calamondin). }\end{array}$ & Faustrimedin & 1466 & 311.3 & 0.96 \\
\hline
\end{tabular}

${ }^{\mathrm{z}}$ For each life stage, seed-source genotypes are listed in order of decreasing colonization of their seedling test populations. Members of the Rutaceae vary greatly in their incidence of nucellar embryony (reviewed in Frost and Soost, 1968) and so some of the plants tested were essentially genetically identical to the seed parent, whereas others represent half-sib families with only the seed parent known.

parts of the world, there is significant interest in the role of this host plant in the maintenance and possible amplification of HLB (Damsteegt et al., 2010; Lopes et al., 2010). There is some controversy over whether the "orange jasmine" commonly found as a host for D. citri in Florida and Brazil is M. paniculata or $M$. exotica, because the two names at times have been used interchangeably, but recent molecular evidence suggests that $M$. exotica can be treated as a synonym for $M$. paniculata and may possibly represent $M$. paniculata var. ovatifoliolata (Ranade et al., 2006). In the current study, two test populations of $M$. paniculata were surveyed. Seedlings of Murraya paniculata identified by the CRC number 1637 was in the highest groups for the presence of adults and eggs, and according to the Citrus Variety Collection, the plant from which seeds for this study were derived was received as a live plant from W.T. Swingle in 1926. The Murraya paniculata associated with the CRC number 3171, which was in the highest test population group for egg presence, is according to the Citrus Variety Collection probably var. ovatifoliolata and the parent plant was germinated from seed received by the Horticulture Department at the University of Hawaii Agriculture Experiment Station in 1955.

Multiple seed-source genotypes of several other Citrus species provided multiple test populations that were found to be highly susceptible to $D$. citri, including $C$. maxima (pummelo), C. medica (citron), and C. limonia (rangpur lime). All six pummelo test populations surveyed - from the seed sources 'Egami Buntan' (CRC 3959), 'Mato Buntan' (CRC 3945), 'Reinking' (CRC 3805), 'Kao Pan' (CRC 2242), 'Kao Panne' (CRC 2248), and 'Pomelit' (CRC 4026)-were in the highest group for egg susceptibility. Two of the three different citron test populations ['Diamante'(CRC 3523) and 'South Coast Field Station' (CRC 3546) seed sources] and each of two test populations of rangpur limes ['Santa Barbara red' (CRC 712) and 'Lamas' (CRC 3919) seed sources] were in two of three life stage highest susceptibility groups.

How plant material with mixed susceptibility to different life stages of $D$. citri may influence the overall epidemiology of HLB is difficult to interpret. For HLB transmission, adults represent a key life stage because their mobility allows them to acquire the pathogen and then inoculate subsequent host plants. Plants that may be used by adults for feeding, but infrequently used for oviposition and subsequent nymphal development, may still act as an important source of infection for immigrating adults. However, a recent study reported that in laboratory studies, nymphs reared on HLB-infected plants were more likely to acquire the bacterium than adults (Pelz-Stelinski et al., 2010). Therefore, an infected plant that is host to large numbers of developing nymphs may be a more important source of infected adults. How the pathogen manifests in different host plant genotypes is also a key element in predicting how the disease moves through an area.

Genotypes that express a level of resistance against infestation by $D$. citri may be using biochemical and/or behavioral mechanisms. Some genotypes highly attractive to ovipositing females (and thus highly susceptible to becoming infested by adults and eggs) may contain traits resistant to nymphs. There are multiple examples in nature of negative correlations between oviposition preference and offspring performance (Thompson, 1988; Wise et al., 2008). Plant material that is attractive to ovipositing females but contains compounds that adversely affect developing nymphs may have value in reducing the population equilibrium of $D$. citri in a grove. It is also possible that a lack in correspondence in susceptibility among the life stages in a test population may have been influenced by sampling date. Adults are mobile and eggs are only in the field for $\approx 4$ days at $25{ }^{\circ} \mathrm{C}$ before hatching; thus, the presence and abundance of these two life stages are more difficult to reliably document. On the other hand, surviving nymphs may be on a plant for 12 or more days depending on temperature, host plant, and other factors (Tsai and Liu, 2000).

A strength of this study was the ability to screen seedlings derived from numerous diverse genotypes in the field that were exposed to a natural population of $D$. citri rather than relying on cage or greenhouse experiments with colony-reared D. citri. However, in attempts to sample all replicates in a reasonable time period, categorical counts were used as a compromise between merely recording presence and counting large numbers of eggs, nymphs, and adults on each replicate. Because the primary purpose of this survey was to identify potential sources of resistance, categorical counts were adequate for this level of discernment. In future studies that attempt to identify more subtle differences in susceptibility, full counts may identify smaller genotype effects.

In summary, the work described here has identified a few genotypes providing seedlings expressing either complete or high levels of resistance to D. citri based on reduced infestation levels of the psyllid in a free-choice situation. It has also defined the relative level of susceptibility to the three life stages of $D$. citri among seedlings of many Citrus species and more distant members of the Aurantioideae subfamily. Because of its importance in citrus breeding programs, future work will include an in-depth investigation into probable resistance in $P$. trifoliata. Probable resistance in other genotypes avoided by $D$. citri should be explored, and an expanded survey within the Aurantioideae and other Rutaceae genera not represented in the study presented here should be carried out.

\section{Literature Cited}

Aubert, B. 1990. Integrated activities for the control of huanglungbin-greening and its vector Diaphorina citri Kuwayama in Asia. Proc. of the 4th Intl. Asia Pacific Conf. on Citrus Rehabilitation. p. 133-144.

Barkley, N.L.A. 2003. Genetic diversity in a citrus germplasm collection characterized with simple sequence repeat markers. $\mathrm{PhD}$ diss., University of California, Riverside, CA. Dec. 2003.

Barrett, H.C. and A.M. Rhodes. 1976. A numerical taxonomic study of affinity relationships in cultivated Citrus and its close relatives. Syst. Bot. 1:105-136

Bayer, R.J., D.J. Mabberley, C. Morton, C.H. Miller, I.K. Sharma, P. Pfeil, S. Rich, R. Hitchcock, and S. Sykes. 2009. A molecular phylogeny of the orange subfamily (Rutaceae: Aurantioideae) using nine cpDNA sequences. Amer. J. Bot. 96:668-685.

Bové, J.M. 2006. Huanglongbing: A destructive, newly emerging, century-old disease of citrus. J. Plant Pathol. 88:7-37.

Bowman, K.D., J.P. Shapiro, and S.L. Lapointe. 2001. Sources of resistance to Diaprepes weevil in subfamily Aurantioideae, Rutaceae. HortScience 36:332-336.

Chen, J., X. Deng, X. Sun, D. Jones, M. Irey, and E. Civerolo. 2010. Guangdong and Florida 
populations of 'Candidatus Liberibacter asiaticus' distinguished by a genomic locus with short tandem repeats. Phytopathology 100: 567-572.

da Graça, J.V., J.V. French, P.S. Haslem, M. Skaria, M. Sétamou, and B. Salas. 2008. Survey for the Asian citrus psyllid, Diaphorina citri, and citrus huanglongbing (greening disease) in Texas. Subtrop. Plant Sci. 60:21-26.

Damsteegt, V.D., E.N. Postnikova, A.L. Stone, M. Kuhlmann, C. Wilson, A.J. Sechler, N.W. Schaad, R.H. Brlansky, and W.L. Schneider. 2010. Murraya paniculata and related species as potential hosts and inoculum reservoirs of 'Candidatus Liberibacter asiaticus', causal agent of Huanglongbing. Plant Dis. 94:528533.

Engler, A. 1931. Rutaceae, p. 187-359. In: Engler, A. and K. Prantl (eds.). Die natürlichen Pflanzenfamilien. 2nd Ed., Vol. 19a. Engelmann, Leipzig, Germany.

French, J.V., C.J. Kahlke, and J.V. da Graça. 2001. First record of the Asian citrus psylla, Diaphorina citri Kuwayama (Homoptera: Psyllidae) in Texas. Subtrop. Plant Sci. 53:14-15.

Frost, H.B. and R.K. Soost. 1968. Seed reproduction: Development of gametes and embryos, $p$. 290-324. In: Reuther, W., L.D. Batchelor, and H.J. Webber (eds.). The citrus industry. Vol. 2. Anatomy, physiology, genetics, and reproduction. Univ. California, Berkeley, CA.

Halbert, S.E. 1998. Entomology section. Triology 37:6-7.

Halbert, S.E. 2005. The discovery of huanglongbing in Florida. Proc. of the 2nd International Citrus Canker and Huanglongbing Research Workshop. Florida Citrus Mutual, Orlando, FL, 7-11 Nov., Paper H-3. p. 51.

Halbert, S.E. and K.L. Manjunath. 2004. Asian citrus psyllids (Sternorrhyncha: Psyllidae) and greening disease of citrus: A literature review and assessment of risk in Florida. Fla. Entomol. 87:330-353.

Hall, D.G. and L.G. Albrigo. 2007. Estimating the relative abundance of flush shoots in citrus, with implications on monitoring insects associated with flush. HortScience 42:364-368.

Hall, D.G., M.G. Hentz, and R.C. Adair. 2008. Population ecology and phenology of Diaphorina citri in two Florida citrus groves. Environ. Entomol. 37:914-924.

International Society for Infectious Diseases. 2004. ProMED mail archive number 20040723.2012. $<$ http://www.promedmail.org $>$.

International Society for Infectious Diseases. 2005. ProMED mail archive numbers 20050910.2683 and 20050404.0976. <http://www.promedmail. org $>$.

International Society for Infectious Diseases. 2008. ProMED mail archive number 20080829.2707. $<$ http://www.promedmail.org $>$.

International Society for Infectious Diseases. 2009. ProMED mail archive numbers 20091126. 4054, 20091110.3892, 20090720.2570, 20090518. 1853 and 20090415.1436. <http://www. promedmail.org $>$.
International Society for Infectious Diseases. 2010. ProMED mail archive number 20100419.1272. $<$ http://www.promedmail.org $>$.

International Society for Infectious Diseases. 2011. ProMED mail archive number 20110223.0593. $<$ http://www.promedmail.org $>$.

Ipe, D. 1987. Performing the Friedman test and the associated multiple comparison test using PROC GLM. Proc. of the 12th Annual SAS Users Group International Conference. SAS Institute, Cary, NC. p. 1146-1148.

Krueger, R.R. and L. Navarro. 2007. Citrus germplasm resources, p. 45-140. In: Khan, I.A. (ed.) Citrus genetics, breeding and biotechnology. CAB International, Wallingford, Oxfordshire, UK.

Lin, K.-H. 1956. Observations on yellow shoot of citrus. Acta Phytopathologica Sin. 2:1-11.

Lopes, S.A., G.F. Frare, L.E.A. Camargo, N.A. Wulff, D.C. Teixeira, R.B. Bassanezi, G.A.C. Beattie, and A.J. Ayres. 2010. Liberibacters associated with orange jasmine in Brazil: Incidence in urban areas and relatedness to citrus Liberibacters. Plant Pathol. 59:1044-1053.

Luthria, D.L., V. Ramakrishnan, G.S. Verma, B.R. Prabhu, and A. Banerji. 1989. Insect antifeedants from Atalantia racemosa. J. Agr. Food Chem. 37:1435-1437.

Martinez, A.L. and J.M. Wallace. 1967. Citrus leafmottle-yellows disease in the Philippines and transmission of the causal virus by a psyllid, Diaphorina citri. Plant Dis. Rpt. 51:692-695.

Mead, F.W. 1977. The Asiatic citrus psyllid, Diaphorina citri Kuwayama (Homoptera: Psyllidae). Fla. Dept. Agr. Consumer Serv. Div. Plant Ind. July Entomology Circular No. 180.

Michaud, J.P. 2004. Natural mortality of Asian citrus psyllid (Homoptera: Psyllidae) in central Florida. Biol. Control 29:260-269.

Moore, G.A. 2001. Oranges and lemons: Clues to the taxonomy of Citrus from molecular markers. Trends Genet. 17:536-540.

Nehru, R.K., K.C. Bhagat, and V.K. Koul. 2004. Influence of Citrus species on the development of Diaphorina citri. Ann. Plant Protection Sci. 12:436-438

Nicolosi, E. 2007. Origin and taxonomy, p. 19-43. In: Khan, I.A. (ed.) Citrus genetics, breeding and biotechnology. CAB International, Wallingford, Oxfordshire, UK.

Pelz-Stelinski, K.S., R.H. Brlansky, and M.E. Rogers. 2010. Transmission Parameters for Candidatus Liberibacter asiaticus by Asian citrus psyllid (Hemiptera: Psyllidae). J. Econ. Entomol. 103:1531-1541.

Rahmani, M. and A.W. Hodges. 2009. Economic impact of Florida's citrus industry, 2007-08. Electronic Data Information Source (EDIS) FE802. Food and Resource Economics Department, University of Florida, Gainesville, FL. 9 Oct. 2010. < http://edis.ifas.ufl.edu/FE802>.

Ranade, S.A., T.S. Rana, A.P. Srivastava, and K.N. Nair. 2006. Molecular differentiation in Murraya Koenig ex. L. species in India inferred through ITS, RAPD and DAMD. Curr. Sci. 9:1253-1258.

SAS Institute. 2008. Statistical analysis system. Version 9.2. SAS Institute, Cary, NC.
Shapiro, J.P., K.D. Bowman, and S.L. Lapointe 2000. Dehydrothalebanin, a source of resistance from Glycosmis pentaphylla against the citrus root weevil Diaprepes abbreviatus. J. Agr. Food Chem. 48:4404-4409.

Shapiro, J.P., K.D. Bowman, and H. Smith. 1997. Resistance of citrus rootstocks and Glycosmis pentaphylla against larval Diaprepes abbreviatus (Coleoptera: Curculionidae) in live root or diet-incorporation assays. Fla. Entomol. 8:471477 .

Shivankar, V.J., C.N. Rao, and S. Singh. 2000. Studies on the citrus psylla, Diaphorina citri Kuwayama: A review. Agr. Rev. 21:199-204.

Swingle, W.T. 1943. The botany of Citrus and its wild relatives of the orange subfamily, p. 129474. In: Batchelor, L.D. and H.J. Webber (eds.). The citrus industry. 1st Ed., Vol. 1. History, world distribution, botany, and varieties. University of California, Berkeley, CA.

Swingle, W.T. and P.C. Reece. 1967. The botany of citrus and its wild relatives of the orange subfamily, p. 190-430. In: Reuther, W., H.J. Webber, and L.D. Batchelor (eds.). The citrus industry. 2nd Ed., Vol. 1. History, world distribution, botany, and varieties. University of California, Berkeley, CA.

Tanaka, T. 1954. Species problem in citrus: A critical study of wild and cultivated units of citrus based upon field studies in their native homes (Revisio Aurantiacearum IX). Japanese Society for Promotion of Science, Tokyo, Japan.

Tanaka, T. 1977. Fundamental discussion of citrus classification. Studia Citrologica 14:1-6.

Thompson, J.N. 1988. Evolutionary ecology of the relationship between oviposition preference and performance of offspring in phytophagous insects. Entomol. Exp. Appl. 47:3-14.

Tsagkarakis, A.E. and M.E. Rogers. 2010. Suitability of 'Cleopatra' mandarin as a host plant for Diaphorina citri (Hemiptera: Psyllidae). Fla. Entomol. 93:451-453.

Tsai, J.H. and Y.H. Liu. 2000. Biology of Diaphorina citri (Homoptera: Psyllidae) on four host plants. J. Econ. Entomol. 93:1721-1725.

Wenninger, E.J. and D.G. Hall. 2007. Daily timing of mating and age at reproductive maturity in Diaphorina citri (Hemiptera: Psyllidae). Fla. Entomol. 90:715-722.

Wise, M.J., J.M. Partelow, K.J. Everson, M.K. Anselmo, and W.G. Abrahamson. 2008. Good mothers, bad mothers, and the nature of resistance to herbivory in Solidago altissima. Oecologia 155:257-266.

Yang, R.Z. and C.S. Tang. 1988. Plants used for pest control in China: A literature review. Econ. Bot. 42:376-402

Yang, Y., M. Huang, G.A.C. Beattie, Y. Xia, G. Ouyang, and J. Xiong. 2006. Distribution, biology, ecology, and control of the psyllid Diaphorina citri Kuwayama, a major pest of citrus: A status report for China. Intl. J. Pest Manage. 52:343-352.

Ziegler, L.W. and H.S. Wolfe. 1981. Citrus growing in Florida. 3rd Ed. The Univ. Presses of Fla., Gainesville, FL. 